\title{
An Integrated Approach to Convert Lignocellulosic and Wool Residues into Balanced Fertilisers
}

\author{
Filippo Marchelli ${ }^{1}$ (D), Giorgio Rovero ${ }^{2}$, Massimo Curti ${ }^{2}$, Elisabetta Arato ${ }^{2}$ (D), Barbara Bosio ${ }^{2, *}$ and \\ Cristina Moliner ${ }^{2} \mathbb{D}$ \\ 1 Faculty of Science and Technology, Free University of Bozen-Bolzano, 39100 Bozen-Bolzano, Italy; \\ filippo.marchelli@edu.unige.it \\ 2 Department of Civil, Chemical and Environmental Engineering, University of Genova, 16145 Genova, Italy; \\ giorgio.rovero@formerfaculty.polito.it (G.R.); massimo.curti@gmail.com (M.C.); \\ elisabetta.arato@unige.it (E.A.); cristina.moliner@edu.unige.it (C.M.) \\ * Correspondence: barbara.bosio@unige.it
}

\section{check for}

updates

Citation: Marchelli, F.; Rovero, G.; Curti, M.; Arato, E.; Bosio, B.; Moliner, C. An Integrated Approach to Convert Lignocellulosic and Wool Residues into Balanced Fertilisers. Energies 2021, 14, 497. https:// doi.org/10.3390/en14020497

Received: 18 December 2020

Accepted: 13 January 2021

Published: 18 January 2021

Publisher's Note: MDPI stays neutral with regard to jurisdictional claims in published maps and institutional affiliations.

Copyright: (c) 2021 by the authors. Licensee MDPI, Basel, Switzerland. This article is an open access article distributed under the terms and conditions of the Creative Commons Attribution (CC BY) license (https:// creativecommons.org/licenses/by/ $4.0 /)$.

\begin{abstract}
Valorising biomass waste and producing renewable energy or materials is the aim of several conversion technologies. In this work, we consider two residues from different production chains: lignocellulosic residues from agriculture and wool residues from sheep husbandry. These materials are produced in large quantities, and their disposal is often costly and challenging for farmers. For their valorisation, we focus on slow pyrolysis for the former and water hydrolysis for the latter, concisely presenting the main literature related to these two processes. Pyrolysis produces the C-rich biochar, suitable for soil amending. Hydrolysis produces a N-rich fertiliser. We demonstrate how these two processes could be fruitfully integrated, as their products can be flexibly mixed to produce fertilisers. This solution would allow the achievement of balanced and tuneable ratios between $\mathrm{C}$ and $\mathrm{N}$ and the enhancement of the mechanical properties. We propose scenarios for this combined valorisation and for its coupling with other industries. As a result, biomass waste would be returned to the field, following the principles of circular economy.
\end{abstract}

Keywords: circular economy; integrated approach; biochar; biomass pyrolysis; wool residue; hydrolysis

\section{Introduction}

The circular economy is becoming the driving force for developing new technologies, as well as for the upgrade of existing productive cycles. As is widely known, the circular economy is based on exploiting potential residual matter in new productive chains or processes such as the generation of energy or new materials. The aim is twofold: on the one hand, to avoid exploiting raw (and possibly non-renewable) sources and, on the other hand, to avoid the cost and impact associated with the disposal of waste materials. This strategy can appropriately tackle some of the most troublesome social and environmental problems we are currently facing, such as climate change, the increase in generated residues because of the increase in population and the depletion of resources [1-12].

Poorly managed farming activities currently pose multiple threats to the environment. Bentsen and colleagues [13] estimated that the average yearly global production of lignocellulosic residues from barley, maize, rice, soybean, sugar cane and wheat in the years 2006-2008 was about $37 \times 10^{8} \mathrm{t}$ (on dry basis). Even though lignocellulosic residues typically have a carbon content of about $45-50 \mathrm{wt} \%$, they are often unexploited. These residues are disposed of in landfills, left on fields or, in the worst case, burned, generating uncontrolled emissions. A recent report from the Food and Agriculture Organization (FAO) of the United Nations estimated that $38 \times 10^{7} \mathrm{t}$ of maize, rice paddy, sugar cane and wheat residues were burned in 2016, resulting in total emissions of $299 \times 10^{5} \mathrm{t}$ of

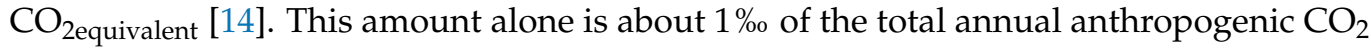
emissions [15]. The advantages of giving new purposes to these residues appear obvi- 
ous: they are low-to-negative cost materials and impacts caused by their disposal could be avoided.

While considering the problem on a global scale can help understand its magnitude, the possible solutions must be provided locally. One of the reasons lies in the properties of biomass: its low density makes transporting it for long distances expensive and unsustainable [16]. In fact, lab-scale studies have provided countless opportunities for the exploitation of such materials [17-23]. However, the feasibility of these technologies at larger scales should always be assessed in order to evaluate their actual viability [24-26]. Several alternatives have been proposed to exploit lignocellulosic residues, such as combustion [27], gasification [28], pyrolysis [29] and fermentation [30] to produce energy and/or new products. In particular, the thermal decomposition of biomass (i.e., pyrolysis) produces a solid residue with a high carbon content and unique structure that has several possible applications, including soil amendment [31].

The exploitation of other types of residues is still less established. Another notable example related to farming activities is sheep wool. Sheep represent a noteworthy species for food security: they are efficient and can adapt to the most diverse climate, from the cold of Iceland to wastelands in Africa, Asia and Australia. Compared to intensive farming, the natural sheep behaviour of searching for food in dry areas (typical of least developed countries) produces less detrimental gaseous emissions and has beneficial effects on the soil [32]. Due to these aspects, researchers believe that they will become the main source of meat in the forthcoming years [32]. Recent studies on sheep husbandry performed in developed countries [33-35] reported that enteric fermentation causes the greatest impact on the environment. Moreover, the production of $1 \mathrm{~kg}$ of wool is more impactful compared to the same amount of meat and milk.

The EU has the second largest population of sheep (98.3 million units in 2016), after China (162 M units in 2016) and before Australia (67.5 M units in 2016) [14]. Northern and central European countries mainly raise sheep for their meat, while southern European countries do it for dairy products. In both cases, the produced wool has a low quality, which cannot compete with that of the main producer countries (China, Australia and New Zealand). Moreover, the price of wool has decreased due to the increasing demand for low-cost synthetic fibres. Nowadays, European farmers see wool as a residual product which is hard to dispose of [36]. Its properties prevent both landfilling and combustion, and thus illegal disposal practices are often applied. In the last decades, researchers foresaw that low-grade wool could be given new purposes, and showed that it could be exploited in the building, medical and agricultural sectors [37]. In this framework, water hydrolysis was recently proposed as a way to transform wool into a low-cost nitrogen-rich fertiliser, without employing chemicals [38,39].

In general, the agriculture and food industries showcase several possibilities for their fruitful integration [40-47]. Within the aforementioned framework, we propose an integrated approach that allows valorising both agricultural and wool residues; Figure 1 graphically summarises its logic. Agricultural residues can be pyrolysed to produce biochar. Conversely, residual wool can be hydrolysed using superheated water to produce a nitrogen-rich fertiliser. These two products can be pelletised together to obtain a balanced and tuneable fertiliser, possibly overcoming problems caused by poor mechanical properties and nutrient availability $[43,48,49]$. The integrated approach will be brought to life in the framework of the "Biochar" project, funded by the Piedmont region (Italy). The project aims at showing the feasibility of an innovative scaled-up unit, based on the results obtained with two-stage [50] and multiple spouted bed [51,52] units. It is based on the positive outcomes of two past projects: the LIFE+ GREENWOLF Project [53] and the Valentex2 project [54]. In particular, the conclusions of the latter suggested that this technology can only be economically sustainable if by-products are valorised, if low-to-negative cost materials are converted, and if there is a tight cooperation with local industries in terms of offer and demand. All these aspects appear in favour of coupling it with the hydrolysis of wool waste, another waste-valorisation technology. Wood and agricultural residues are 
indeed very abundant in the region of Piedmont and fostering their energetic valorisation is a noteworthy opportunity [55].

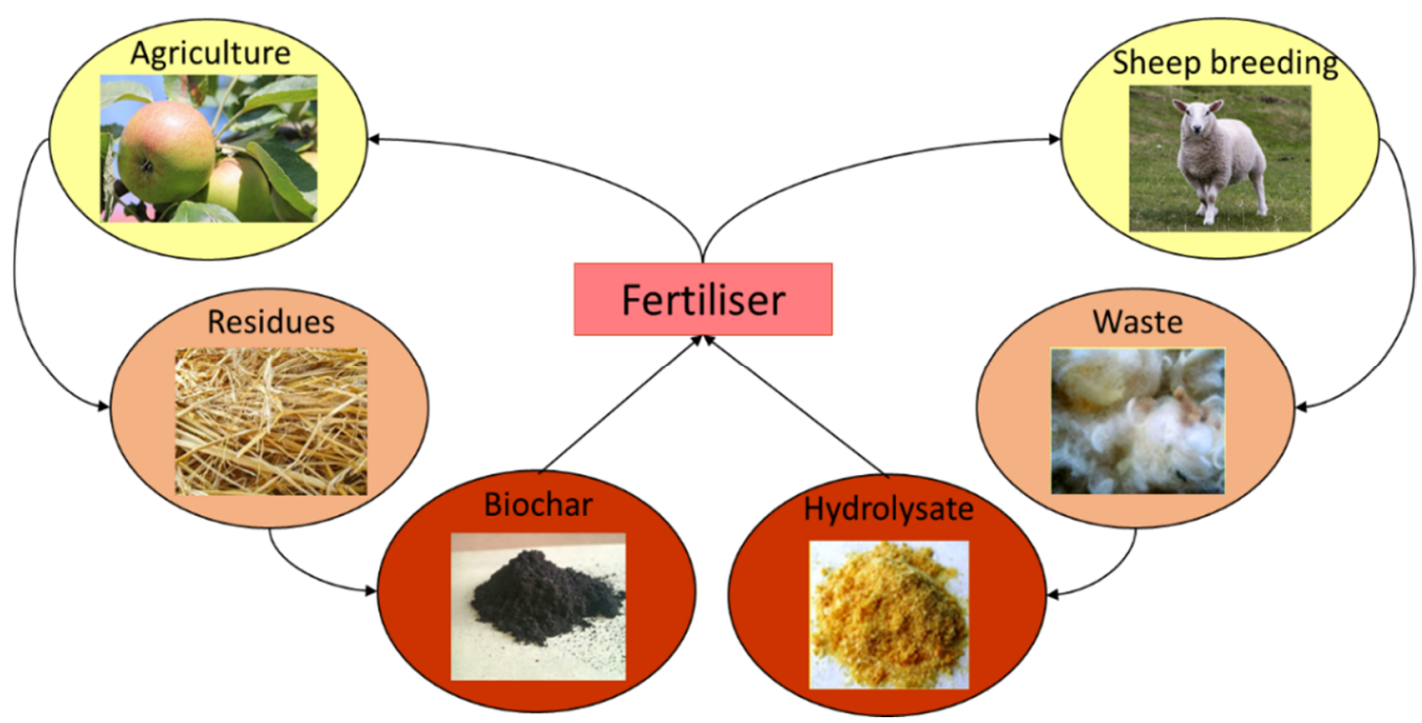

Figure 1. The proposed integrated approach to valorise agricultural and wool residues.

The aim of this work is to discuss the feasibility of this integrated approach: to our knowledge, it has never been mentioned in the literature before. After a succinct but complete overview of the literature for these two technologies, several scenarios are proposed, proving the flexibility of the approach and the possible ways to optimise the process from the material and energetic points of view. Finally, we broaden our perspective to holistically discuss how the process could be integrated with other industries.

\section{Agricultural Residues and Pyrolysis}

The concept of exploiting biomass for energetic purposes dates back to when humankind learnt to control fire. Nonetheless, this research field is still remarkably active due to the challenges in increasing the overall conversion and efficiency of the various processes. Choosing the most suitable valorisation technique depends on the properties of the biomass, on the desired output and on other factors, such as the plant size and location [20,56]. Thermochemical processes are classified depending on the amount of oxidising agent fed to the reactor, compared to the amount required for the stoichiometric oxidation. In pyrolysis, no oxidising agent is fed, and the reactions take place due to the thermal decomposition of the material at high temperature. Biomass is hence converted into three phases: a solid phase (the biochar), a condensable phase (the tar or bio-oil) and a gaseous phase (the syngas or pyrogas). The relative amount of these three phases can be tuned through the variation of the operative conditions. Pyrolysis attracts much interest due to the possibility of obtaining different products in reasonable quantities.

Fast and flash pyrolysis are aimed at maximising the bio-oil yield, which can reach up to $80 \mathrm{wt} \%$ of the raw material. Fast pyrolysis requires biomass sizes lower than $2 \mathrm{~mm}$, high heating rates $\left(>10-200{ }^{\circ} \mathrm{C} / \mathrm{s}\right)$ and low residence times $(0.5-10 \mathrm{~s})$, while the requirements are even stricter for flash pyrolysis [22]. Catalysts can also aid optimising the outcome [57-59]. This bio-oil can be further used for energetic purposes, even though pre-treatments are usually necessary. Conversely, slow (or conventional) pyrolysis is aimed at maximising the biochar yield, which is typically about $35 \mathrm{wt} \%$ and that, under adequate operating conditions, can be up to $90 \mathrm{wt} \%$. Slow pyrolysis requires much higher residence times (up to days), and has less constraints on the particle sizes (typically 5-50 mm) [22].

Charcoal was first discovered several thousand years ago, and today it is considered the first synthetic material ever produced [60]. Biochar is the charcoal produced from 
the pyrolysis of biomass. The properties of biochar may notably vary depending on the conversion technology, initial feedstock and operative conditions. As an example, Table 1 summarises the characterisation of biochar samples obtained from various feedstocks and at different conditions.

Table 1. Data from the literature for biochar production from different feedstocks.

\begin{tabular}{|c|c|c|c|c|c|c|}
\hline Noted as & Feedstock & $\begin{array}{c}\text { Pyrolyser } \\
\text { Temperature }\left({ }^{\circ} \mathrm{C}\right)\end{array}$ & $\begin{array}{c}\text { Biochar Yield } \\
(w t \%)\end{array}$ & $\begin{array}{c}\text { Biochar C } \\
\text { Content (wt } \%)\end{array}$ & $\begin{array}{c}\text { Biochar N Content } \\
(\mathbf{w t} \%)\end{array}$ & Ref. \\
\hline RAP & Rapeseed plant & $400-900$ & $39.4-27.9$ & $71.34-79.86$ & $1.35-1.57$ & [61] \\
\hline PIS & Pinewood shavings & $100-700$ & $99.8-22.0$ & $50.6-92.3$ & $0.04-0.08$ & [62] \\
\hline PES & Peanut shells & $300-700$ & $36.9-21.9$ & $68.27-83.76$ & $1.91-1.14$ & [63] \\
\hline SES & Sewage sludge & $300-700$ & $70.1-50.3$ & $30.72-22.40$ & $4.11-1.73$ & [64] \\
\hline PIW & Pine wood & $300-600$ & $49.8-28.3$ & $69.24-85.68$ & $0.31-0.34$ & [65] \\
\hline
\end{tabular}

Biochar has been proved to be suitable for a wide range of applications, including [66]: soil amendment [67], adsorption of liquid [68] and gaseous [69] contaminants, catalysis [70], water treatment [71] and others, as explained in detail in the review article by Cha et al. [72]. Such remarkable performances are due to its key properties: a high carbon content, a porous structure and a valuable presence of mineral species. Biochar is also still vastly used as a fuel in developing countries. Its production methods often adopt outdated technologies: Woolf et al. [73] estimated that if optimised processes were adopted, about $130 \times 10^{9} \mathrm{t}$ of $\mathrm{CO}_{2 \mathrm{eq}}$ emissions could be avoided in a century.

In this work, we focus on the use of biochar for soil amendment to establish a closed circular economy loop: pyrolysis of agricultural residues to produce biochar, subsequently used to foster the growth of new crops. The use of biochar for this purpose has been extensively studied in the past years $[31,67,72,74,75]$, and these advantages are generally pointed out [72]:

- biochar can neutralise acidic soils due to its basic $\mathrm{pH}$;

- biochar contains N, P, Ca and K that can act as nutrients, either directly or for microorganisms;

- biochar increases the soil porosity, favouring the growth of microorganisms;

- biochar sequestrates its carbon content in the soil in a stable way, reducing the amount of carbon dioxide in the atmosphere.

There are a wide number of existing technologies used to carry out pyrolysis reactions. The detailed review article by Garcia-Nunez and colleagues [76] offers an overview on the development of different devices and their categorisation. Pyrolysers are often optimised for different types of biomass. A pre-treatment phase is usually required to satisfy the reactor requirements in terms of size and shape of the particles. This limit could be partially overcome using spouted bed reactors, a particular type of fluidised bed reactor. Thanks to their fluid dynamic regime $[77,78]$, they are suitable to process coarse, irregular and sticky particles, which can cause problems to other devices. Most notably, a proper choice of the inlet gas flow rate can ensure the lack of segregation phenomena. Their application in several processes has been studied, including biomass gasification [79-81] and pyrolysis [82,83]. In particular, Niksiar and Nasernajad [84] described the use of spouted beds for the production of biochar from pistachio shells. The new reactor being built for the Biochar process is based on the combined concepts of two-stage [50] and multiple-unit $[51,85]$ spouted beds. Its structure and fluid dynamics have been described in a recent experimental work [52] and its suitability has been confirmed through computational fluid dynamic (CFD) simulations [86], based on a previously-validated approach [87-89].

\section{Wool Residues and Hydrolysis}

Currently, about 2.4 million tonnes of wool are produced per year, $10 \%$ of which is produced in Europe [90]. Sheep breeding in Italy and in Europe are mainly aimed at satisfying the food industry and the demand for dairy products. Wool from these sheep is 
characterized by a medium-to-low quality and only a minor part $(<25 \%)$ [91] is used in the textile market. Therefore, the wool obtained from the shearing of breeding sheep is a byproduct that needs to be disposed of. In Italy the situation is even worse: in a 2015 article, Vagnoni and colleagues [36] estimated that the 6.3 million sheep of the country produce about 14,000 t of wool and only $5 \%$ of it is sold for textile purposes. The article describes three projects developed in different Italian regions aimed at finding other purposes for the waste wool, and the authors point out that only innovative approaches with joined efforts from different entities may overcome the current problems.

According to a European law [92], waste wool must be disposed of as a special waste, due to its potential harmful characteristics (presence of excrement residues and pathogens). Storage and transport must also be done according to specific regulations. The proper disposal of waste wool is thus associated to high costs (around $150 € /$ ton [93]). This results in the increase in burning or burial alternatives, leading to serious environmental impacts: contrarily to other textile residues [93], wool residues cannot be burned easily. Moreover, they are bio-degraded in rather long times.

For the above reasons, eco-sustainable processes that permit avoiding disposal have been developed, providing a new use for something that is still seen as a waste. Some of these processes are summarised in the recent review article by Rajabinejad and colleagues [37]. Among the possible uses, waste wool can be recycled to produce thermal or acoustic insulation panels or other kinds of filling materials [94-96]. However, especially for greasy wool, it is necessary to perform an expansive washing cycle that eliminates dirty and extraneous substances, together with the disinfection due to pathogenic microorganisms. Recent studies have also proven the suitability of wool for more specific applications, such as the adsorption of heavy metals following a suitable chemical treatment [97]. Finally, waste wool can be employed for soil amendment in its original state [98]. If previously composted, Hustvedt and colleagues [99] showed that it is more convenient to mix it with other types of vegetal biomass. However, in some cases it may be more convenient to hydrolyse wool, so as to enhance its properties before of applying to soils.

Hydrolysis is a chemical process carried out in acid or basic environments, which degrades proteins to their constituents, oligo-peptides and amino acids, breaking also the disulphide bridges present in the keratin molecule. Wool is composed of a biological protein fibre, keratin, naturally biodegradable [100-102]. Several elements can be obtained from its decomposition: the most abundant ones are $\mathrm{C}$ and $\mathrm{N}$, but $\mathrm{K}, \mathrm{P}, \mathrm{Na}$ and Fe are also present [103]. Wool can be hydrolised with the aid of chemical compounds [104], and researchers have shown that the product has beneficial effects on the soil [105]. This approach is however debated, due to the potential impact of the employed chemicals. In this framework, Petek and Marinšek Logar [106] recently reviewed the exploitation of waste wool as an organic substrate, highlighting that the aid of enzymatic or microbial processes may be more recommendable. Some recent studies confirmed the validity of enzymatic hydrolysis $[107,108]$, while another showed that hydrolysis can also be achieved through the action of microwaves [109].

The LIFE+ GREENWOLF Project [53] established a process in which the wool hydrolysis is performed only with saturated steam under pressure and without the use of other chemicals. This makes the process environmentally sustainable and eliminates the cost of purchasing chemicals. The feasibility of this process was demonstrated through several devices, starting from laboratory tests up to the construction of a reactor capable of treating from $10 \mathrm{~kg}$ to $100 \mathrm{~kg}$ per cycle [39]. Residence time and temperature are the key parameters of the process: the first one ranges between 30 and $90 \mathrm{~min}$, while the second one from 170 to $185^{\circ} \mathrm{C}$. The hydrolysed wool yield varies from $1: 1$ up to about $1: 2$. Thus, from each $\mathrm{kg}$ of treated wool, from 2 to $3 \mathrm{~kg}$ of hydrolysed protein can be obtained. The project demonstrated that waste wool can undergo a hydrolysis process that degrades the proteins. This process does not require any pre-treatment phase and satisfies the sterilisation requisites. The final product has the characteristics of a soil improver and fertiliser, and it can be used to redevelop exhausted land for cultivation or breeding itself, as proved by germination 
tests. After leaving the hydrolysis reactor, the hydrolysate is wet and has an unpleasant odour, comparable to other common organic fertilisers. However, if subjected to a drying phase, the material becomes practically odourless.

The reaction time directly affects the density and viscosity of the product: for short reaction times the hydrolysis is partial, and the product appears gelatinous and semi-solid, while for longer times the hydrolysate will be liquid. It is not possible to suggest a defined optimum, since the market can require solid materials (with slow release time) or liquid materials (with fast release time). Furthermore, the composition in terms of nutrients is slightly different, as the needs for different plants and crops are different. The use of hydrolysed wool is promising because it contains primary nutrients such as nitrogen, carbon, phosphorus, potassium, ammonia and several micro-nutrients important for the plant health (B, Mn, Ni, Cu, Zn). The composition of the hydrolysed wool [39] is reported in Table 2. As the Table shows, the variation of the parameters is quite weak, especially with the larger initial mass. Therefore, it makes more sense to work with a low residence time, reducing the energetic demand.

Table 2. Composition of the greasy wool and of the hydrolysed wool.

\begin{tabular}{|c|c|c|c|c|c|c|}
\hline Sample Batch Mass (kg) & Process Time (min) & $C(w t \%)$ & $N(w t \%)$ & $P(w t \%)$ & $K(w t \%)$ & $C / N$ Ratio (wt) \\
\hline Greasy wool & $\mathrm{n} / \mathrm{a}$ & 32.52 & 7.62 & 0.05 & 2.33 & 4.26 \\
\hline \multirow{3}{*}{6.5} & 30 & 14.19 & 5.09 & 0.03 & 0.55 & 2.78 \\
\hline & 60 & 8.52 & 3.9 & 0.02 & 0.58 & 2.18 \\
\hline & 90 & 8.95 & 3.9 & 0.02 & 0.56 & 2.29 \\
\hline \multirow{3}{*}{10} & 30 & 15.08 & 4.21 & 0.03 & 1.25 & 3.58 \\
\hline & 60 & 16.47 & 4.88 & 0.02 & 1.58 & 3.38 \\
\hline & 90 & 15.00 & 4.22 & 0.02 & 1.36 & 3.55 \\
\hline
\end{tabular}

Microorganisms decompose organic matter into soil using carbon as a source of energy and nitrogen as a constituent of cellular structures. It follows that the $C / N$ ratio is a crucial factor for the characterisation of a soil. High values of $C / N(>10)$ promote the humification process, which enriches the soil with organic molecules increasing fertility. For lower values of $C / N$, the mineralisation reaction is favoured by making a large quantity of nitrogen available for the growth of the plant; this is the case of the wool hydrolysate obtained in these tests (the $C / N$ ratio is in the range 2.18-4.26). The optimal value of $C / N$ depends on the chosen application, and can also be tuned after the hydrolysis process, with the added aim of enhancing the handleability of the material. One way to do this is mixing the hydrolysed wool with pyrolytic biochar, obtaining a balanced and suitable fertiliser.

\section{The Use of Both Residues to Produce Fertilisers}

The hydrolysed protein, in its solid and gelatinous form, is sticky and difficult to move and dose. Mixing it with an inert absorbent material is convenient to obtain pellets that are easy to transport and dose. With this aim, the hydrolysed product may be combined with the biochar obtained from the pyrolysis of agricultural residues. This fact brings a double advantage: enhanced dosage properties given from the absorption capability of biochar and an optimisation of the $C / N$ ratio due the high carbon content of the biochar. Such a bio-fertiliser could thus be obtained from an integrated process that joins the valorisation of sheep breading waste and agricultural waste, promoting the best properties of both residues. It represents a valid example of circular economy and green chemistry, connecting two different economic activities and creating a product that can aid them both.

As mentioned in the previous Section, there is no fixed optimal value of the $C / N$ ratio. The value must be chosen depending on the soil and crop necessities to provide the required contribution. Looking at the overall production chain of the balanced fertiliser, the key resides in the adequate tuning of pyrolysis and hydrolysis conditions to achieve 
the desired properties for the final product. In this Section, we propose and show four different scenarios to tune the properties of the final product:

- effect of varying the pyrolyser temperature with fixed inlet flow rates of biomass and wool (Section 4.1);

- effect of varying the inlet wool flow rate with fixed working conditions in the pyrolyser (Section 4.2);

- effect of varying the biochar amount with fixed working conditions in both the pyrolysis and hydrolysis sections (Section 4.3);

- $\quad$ obtainment of two different fertilisers with different $C / N$ ratios at fixed working conditions in both the pyrolysis and hydrolysis sections (Section 4.4).

In all cases, for the hydrolysed wool, we considered the properties of the material obtained for an initial wool mass of $10 \mathrm{~kg}$ and process time equal to $30 \mathrm{~min}$, with a wool/water ratio equal to 1:1. As it is shown in Table 1, the properties of the hydrolysed wool hardly vary with the process conditions. Hence, it is better to choose a low residence time, in order to minimise the energetic demand. The biochar and hydrolysed wool are mixed to obtain the balanced fertiliser. The $C / N$ ratio of the final product is calculated as:

$$
C / N=\frac{C_{\text {biochar }}+C_{\text {hydrolysed }}}{N_{\text {biochar }}+N_{\text {hydrolysed }}}
$$

in which $C$ and $N$ are the mass of carbon and nitrogen in the material, and the subscript identifies either the biochar or hydrolysed wool. Although there is no reason to believe the final value will be different, this kind of mixing has never been reported in the literature, and therefore it is impossible to compare the $C / N$ ratios obtained through Equation (1) with experimental data. The actual values of $C / N$ will be checked in the future experimental campaign.

\subsection{Variation of the Pyrolyser Temperature}

The properties of the pyrolysis biochar are likely to vary significantly depending on the feedstock biomass and the process conditions. For this reason, we considered the literature data of Table 1 to study the influence of the pyrolysis feedstock and temperature on the final $C / N$ ratio. Figure 2 depicts the trend of the $C / N$ value when all the obtained biochar is mixed with the hydrolysed wool, as a function of the feedstock and temperature (as per Table 1).

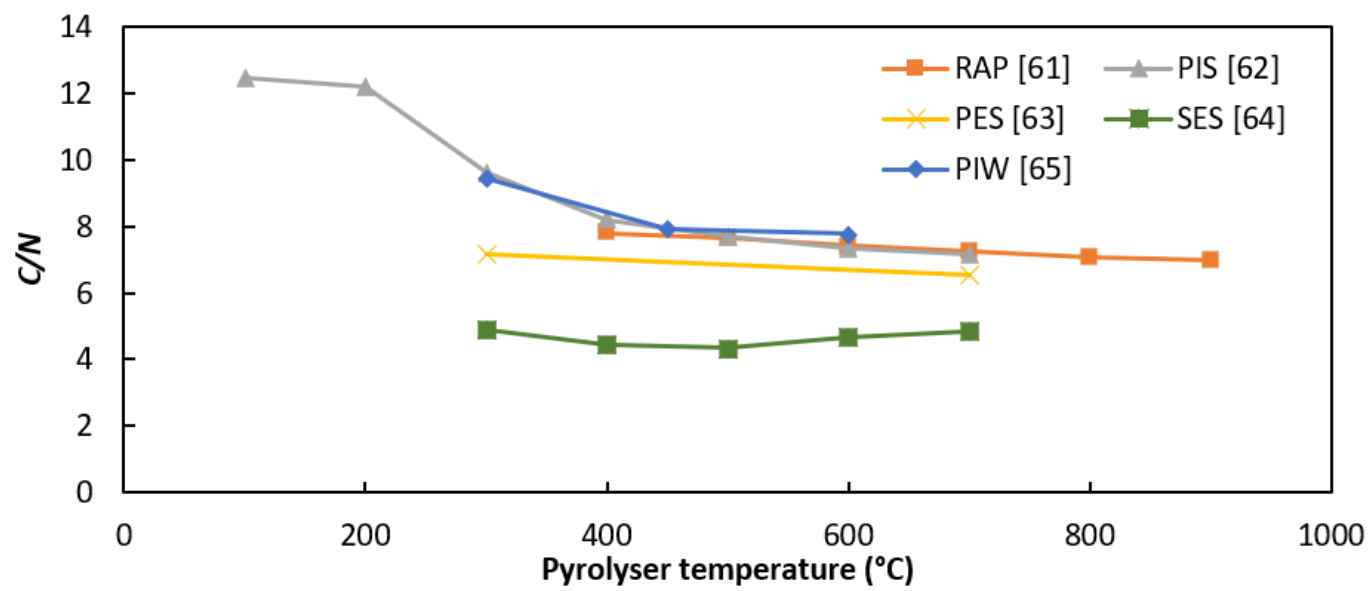

Figure 2. Trend of the $C / N$ ratio for different feedstocks pyrolysed at different temperatures (refer to Table 1 for the acronyms and values).

Here, we supposed to convert 2400 and $1600 \mathrm{~kg} /$ day of biomass and wool, respectively; the first value is the design value of the planned spouted bed pyrolyser, while the second is a value that could be easily obtained with about four $100 \mathrm{~kg}$ batch units [53]. Perhaps 
counterintuitively, the role of the pyrolysis temperature is shown to be quite limited. If we do not consider the low temperatures of 100 and $200{ }^{\circ} \mathrm{C}$ for PIS, the $\mathrm{C} / \mathrm{N}$ ratio is rather weakly affected by the pyrolysis temperature, ranging between six and eight in almost all cases. Biochar from sewage sludge slightly falls out of this range due its initial lower carbon content and higher nitrogen content. Above $300{ }^{\circ} \mathrm{C}$, an increase in the temperature reduces the biochar yield, but increases the carbon content of biochar, so that the total amount of carbon does not vary significantly. Based on this plot, it appears recommendable to work at low temperature (around $300-400{ }^{\circ} \mathrm{C}$ ): this allows a lower energetic demand and higher biochar yield. Nonetheless, some other considerations shall be considered upon an effective implementation of the technology. For example, the temperature can likely affect the porosity of the biochar and the biological availability of the carbon.

\subsection{Variation of the Wool Flow Rate}

If the process has to be optimised for a particular value of $C / N$, it is technically more feasible to adapt the hydrolysis section due to its batch nature. Considering the data for pine wood (PIW) pyrolysis at $450{ }^{\circ} \mathrm{C}$, with biomass feed of 1200 and $2400 \mathrm{~kg} /$ day, we studied the $C / N$ ratio as a function of the amount of wool fed to the hydrolyser. Figure 3 depicts the obtained trends. The graph highlights that if the desired $C / N$ is higher than 10 , the hydrolysis section must not convert roughly more than $33 \mathrm{wt} \%$ of the converted biomass. Conversely, for high values of residual wool fed to the process, the $\mathrm{C} / \mathrm{N}$ ratio obviously tends to become equal to that of the hydrolysed material. It should also be considered that the more wool is converted, the more fertiliser is produced, possibly in excess.

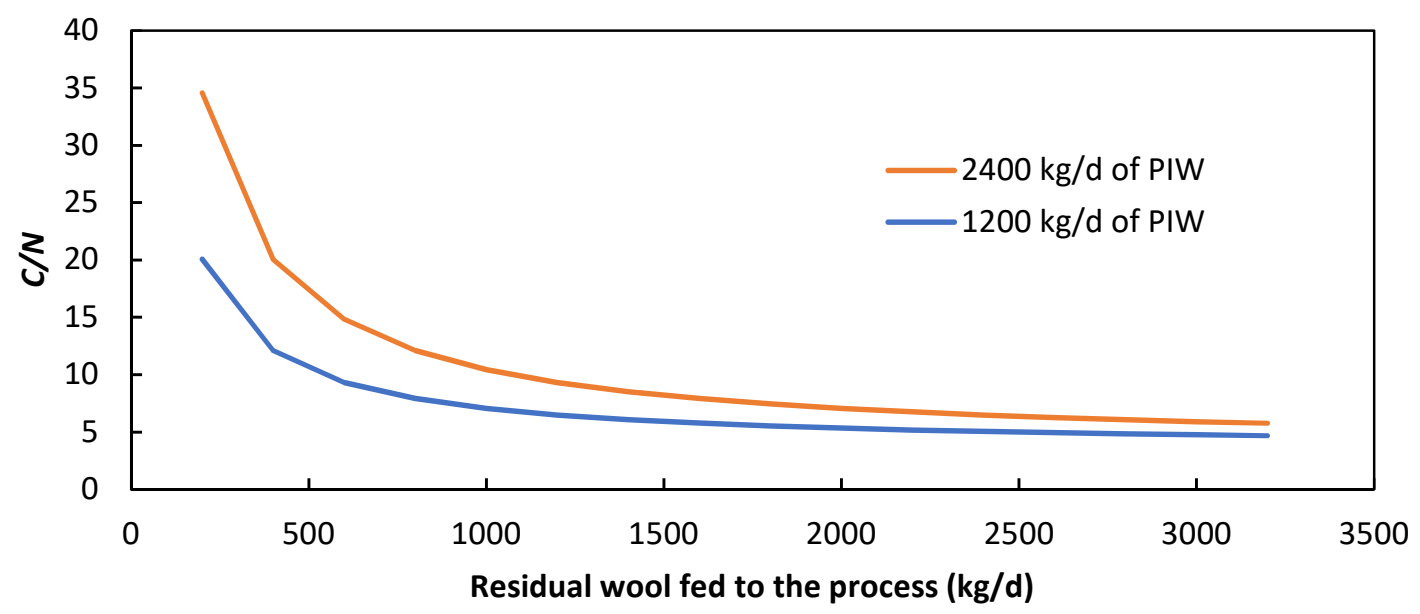

Figure 3. Trend of the $C / N$ ratio as a function of the converted residual wool, for two values of biomass mass flow rate.

\subsection{Variation of the Biochar in the Fertiliser}

While hydrolysed wool can only be employed as a fertiliser, biochar has a plethora of possible applications. If the plant is located in an agro-industrial area, it should be easy to identify other applications for it, such as those reported in Section 2. Thus, it may be interesting to choose a fixed value of converted wool and obtain the required $C / N$ value tuning the amount of biochar that is mixed with it. Figure 4 showcases the results of this analysis obtained for two values of fed residual wool (800 and $1600 \mathrm{~kg} / \mathrm{d}$ ), employing the data for the pyrolysis of PIW at $450{ }^{\circ} \mathrm{C}$. In this case the trend is almost linear: a variation of the amount of biochar modifies both the $C_{\text {biochar }}$ and $N_{\text {biochar }}$ terms in Equation (1). However, the variation range of $N_{\text {biochar }}$ is limited compared to $N_{\text {hydrolysed }}$ resulting in the observed linear trend. This solution is probably the most recommendable. Most notably, it allows the conversion of all the wool into hydrolysate, avoiding the need to dispose of it. Moreover, the final fertiliser may be produced on demand and with the desired properties. As biochar is versatile, its excess can be easily employed for several other applications, even 
within the same plant, avoiding the purchase of external materials. Within this framework, the next Section presents a solution in which two different fertilisers are obtained, and some residual biochar is retained.

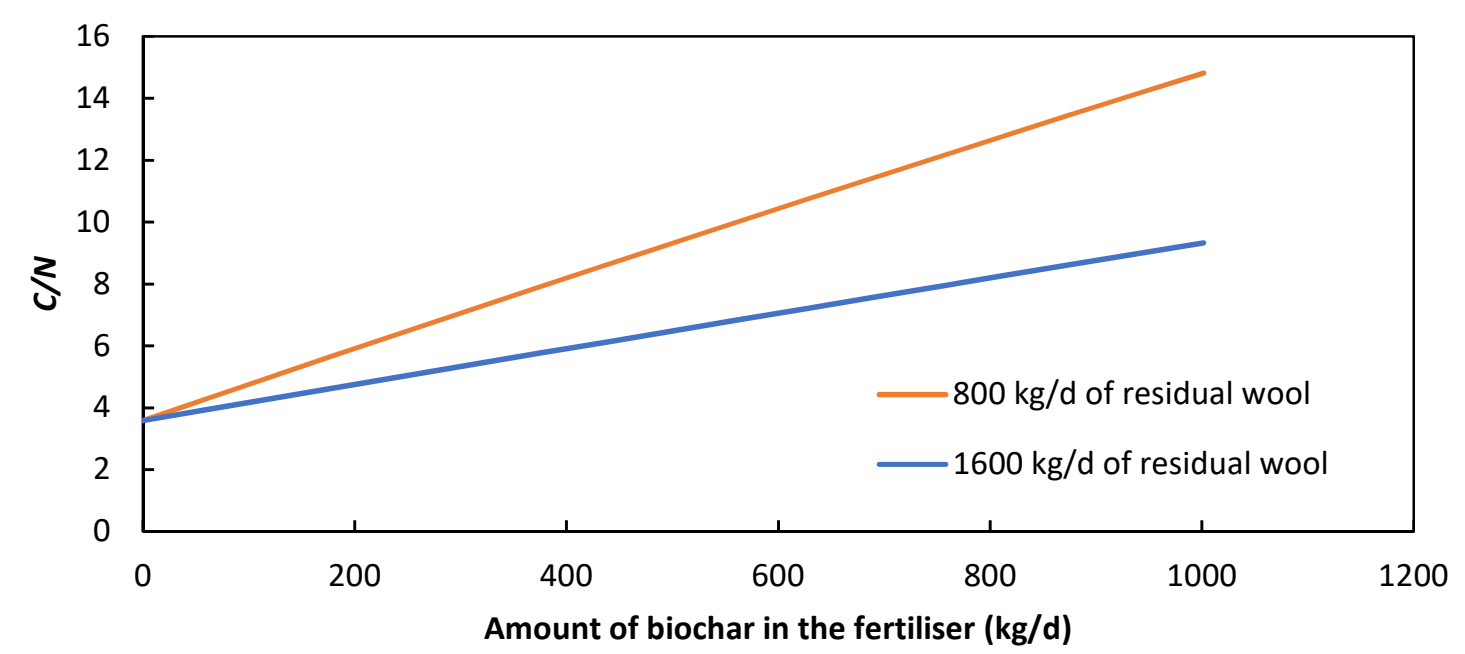

Figure 4. Trend of the $C / N$ ratio as a function of the biochar in the fertiliser, for two values of fed mass of wool per day.

\subsection{Production of Two Different Fertilisers}

Finally, we considered two possible scenarios to continuously produce two different fertilisers with different $C / N$ values. Table 3 shows the obtained results. The data are calculated for the pyrolysis of $1600 \mathrm{~kg} / \mathrm{d}$ of PIW at $450{ }^{\circ} \mathrm{C}$ and the hydrolysis of $600 \mathrm{~kg} / \mathrm{d}$ of wool. In accordance with the previous considerations, about $500 \mathrm{~kg} / \mathrm{d}$ of biochar and $1200 \mathrm{~kg} / \mathrm{d}$ of hydrolysed wool are thus obtained. Excess amounts of biochar of 168 and $193 \mathrm{~kg} / \mathrm{d}$ are also, respectively, obtained. The scenarios are obviously virtually infinite, but all of them can avoid the need for disposing of the residual wool, which is an obvious economic advantage for sheep owners.

Table 3. Two possible scenarios to obtain fertilisers with different $C / N$ ratios.

\begin{tabular}{cccc}
\hline $\begin{array}{c}\text { Biochar Mass Flow } \\
\text { Rate (kg/d) }\end{array}$ & $\begin{array}{c}\text { Hydrolysed Wool Mass } \\
\text { Flow Rate (kg/d) }\end{array}$ & Final C/N & $\begin{array}{c}\text { Fertiliser Mass Flow } \\
\text { Rate (kg/d) }\end{array}$ \\
\hline \multicolumn{6}{c}{ Case 1 } \\
\hline 185.4 & 400 & 12 & \\
147.6 & 800 & 7 & 985.4 \\
\hline 190.9 & Case 2 & 15 & \\
\hline 116.9 & 300 & 6 & 490.9 \\
\hline
\end{tabular}

\subsection{Final Comments}

These results demonstrate the feasibility and flexibility of the proposed combined approach. The optimal conditions must be identified experimentally, on the basis of the agricultural producers' demands. Nonetheless, the above considerations confirm the interest for this process, which can link and aid further industrial realities. In this sense, it could be interesting to broaden the perspective and consider the processes on a larger scale, taking into account more possible connections with related industries.

Figure 5 depicts the scheme of a proposed integrated approach. While the blocks "Sheep breeding" and "Agriculture" have already been described, the block "Textile industry and others" is representative for the human activities that may benefit from biomass energy or biochar, which are numerous, as previously summarised. The cycle may also include the treatment of municipal solid waste, which are often still unexploited and 
disposed of in landfills. The scheme is apparently complex, and it is true that not all these connections may be feasible in all realities, depending on the location of the plants and availability of materials in the area. However, these applications have been proven feasible in the literature, and the abundance of possible integration solutions definitely provides an exciting outlook for the future of agriculture and industry. Once the more plausible links are identified, it will also be interesting to perform a specific life cycle analysis (LCA), so as to assess the impacts associated to the various steps of the supply chain, including transport.

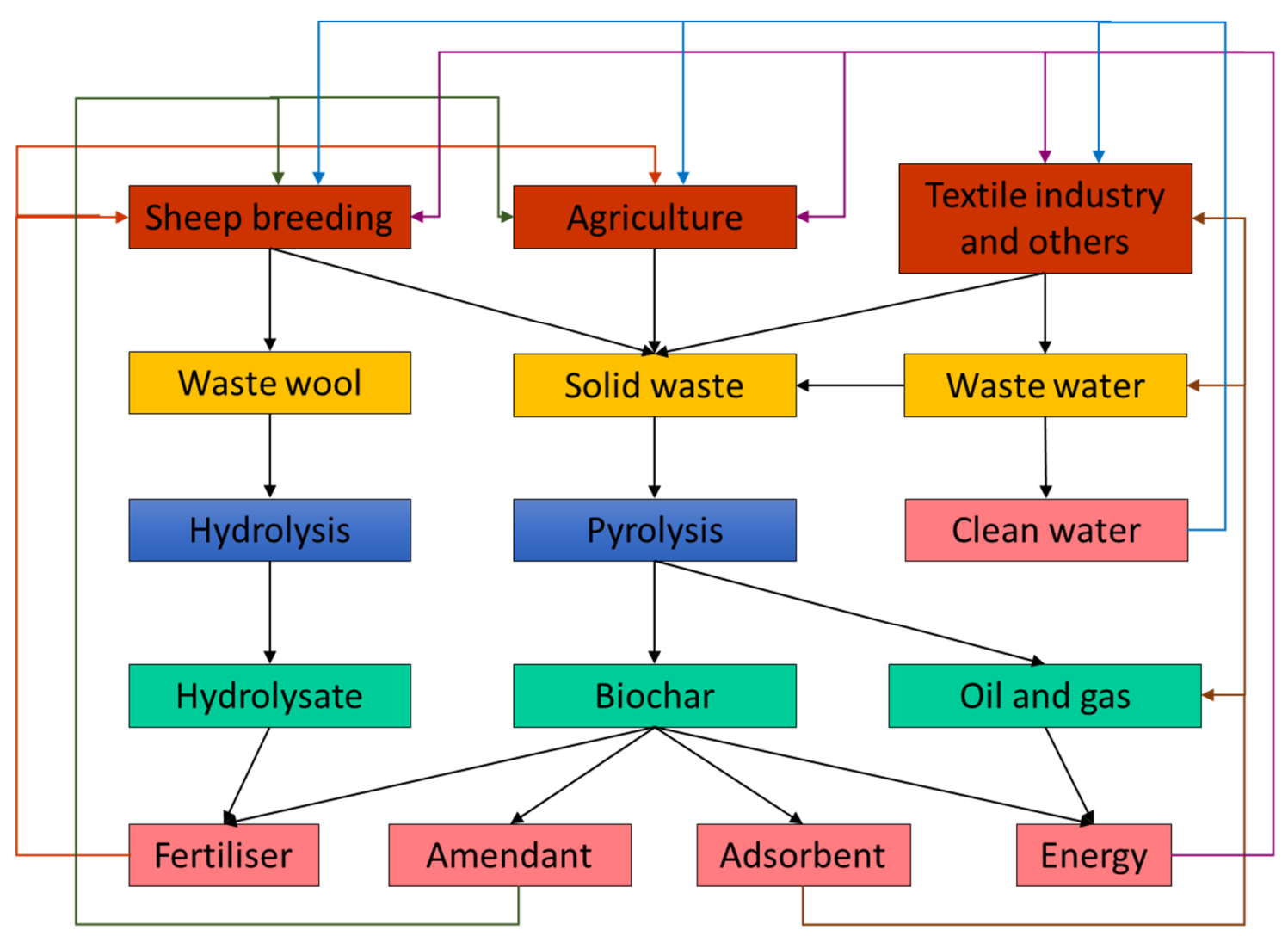

Figure 5. Possible scheme of an integrated process.

The energy demand of the process may be evaluated as well. As previously described, the hydrolysis needs to heat water from ambient temperature to about $170{ }^{\circ} \mathrm{C}$. For $1200 \mathrm{~kg} / \mathrm{d}$ of water, this would correspond to an energetic demand of at least $35.2 \mathrm{~kW}$ (a value calculated with the program Aspen Plus and that does not take into account possible energy losses). This heat demand may be met through an exchange with the hot gaseous stream that exits the pyrolyser. Were it not enough, it may be also partially or completely burned to provide the required energy. Other energetic demands may be originated by other plant units (e.g., compellers, pelletisers, etc.) or by plants in the surrounding area.

These energy demands could be satisfied thanks to the combustion of the products of pyrolysis, providing the added value of a clean energy produced from a carbon-neutral source and enhancing the sustainability of one or more processes. Although the proposed pyrolyser [52] is not operative yet, it is possible to make some initial estimates on the basis of the literature data: the following values are reported in the review article by Kan et al. [22]. The gaseous stream that leaves the pyrolyser comprises the tar (or biooil) and the pyrogas, which usually represent more than $65 \%$ of the initial biomass. The high heating value of the bio-oil usually ranges between 15 and $20 \mathrm{MJ} / \mathrm{kg}$, while the low heating value of common pyrogas ranges between 10 and $20 \mathrm{MJ} / \mathrm{Nm}^{3}$. Biochar can also be employed for energy generation, since it often features interesting high heating values $(20-36 \mathrm{MJ} / \mathrm{kg})$. More precise calculations would depend on the abundance and 
composition of the pyrogas and bio-oil, which in turn depend on the biomass composition, reactor features and working conditions. Given the complexity of such an analysis, it is left for a future optimisation study.

\section{Conclusions}

This work focused on two promising and sustainable biomass valorisation processes: the pyrolysis of lignocellulosic residues and the water hydrolysis of waste sheep wool. The two processes are described with reference to the relevant literature and in light of the achievements of recent projects that focused on these technologies. We show that the carbon-rich product of pyrolysis (biochar) and the nitrogen-rich product of hydrolysis could be mixed to produce a balanced fertiliser with a tuneable $C / N$ ratio. By taking into account several scenarios, we demonstrate the flexibility of the process, and how it is possible to modify the working conditions to obtain the desired product.

The benefits are evident: following circular economy principles, two waste materials coming from agricultural activities are valorised, and returned to the field with the aim of fostering the growth of new biomass. Moreover, as biochar can act as a carbon sequestrator, the carbon balance of the overall process will be negative. If the proposed circularity were achieved, costly, unsustainable or illegal waste disposal practices would be avoided. At the same time, the materials would be re-employed in the same production chain or in a close one, helping farmers not purchase materials generated from non-renewable sources.

The effects of this fertiliser will be studied in future works in the framework of the Biochar project, in which the authors are also developing an innovative scaled-up pyrolyser based on the spouted bed technology.

Author Contributions: Conceptualization: G.R.; data curation: F.M., formal analysis: F.M. and C.M.; funding acquisition: B.B., E.A. and G.R.; investigation: F.M., C.M. and M.C.; methodology: all; project administration: B.B.; resources: M.C.; software: F.M.; supervision: E.A. and B.B.; validation: C.M. and M.C.; visualization: F.M.; writing-original draft: F.M., C.M. and M.C.; writing—review and editing: B.B., E.A. and G.R. All authors have read and agreed to the published version of the manuscript.

Funding: This work was funded by the Piemonte region (Italy) through the "Biochar" project: "Valorizzazione di scarti di origine agroalimentare e di industria tessile per la produzione di char", CUP J97H17000740009.

Institutional Review Board Statement: Not applicable.

Informed Consent Statement: Not applicable.

Data Availability Statement: This work is based on literature data that can be found in the cited references. The only new data that were generated by the authors are entirely reported in Section 4.

Conflicts of Interest: The authors declare no conflict of interest. The funders had no role in the design of the study; in the collection, analyses, or interpretation of data; in the writing of the manuscript, or in the decision to publish the results.

\section{References}

1. Campos, D.A.; Gómez-García, R.; Vilas-Boas, A.A.; Madureira, A.R.; Pintado, M.M. Management of Fruit Industrial By-ProductsA Case Study on Circular Economy Approach. Molecules 2020, 25, 320. [CrossRef]

2. Lahti, T.; Wincent, J.; Parida, V. A Definition and Theoretical Review of the Circular Economy, Value Creation, and Sustainable Business Models: Where Are We Now and Where Should Research Move in the Future? Sustainability 2018, 10, 2799. [CrossRef]

3. Schöggl, J.-P.; Stumpf, L.; Baumgartner, R.J. The narrative of sustainability and circular economy-A longitudinal review of two decades of research. Resour. Conserv. Recycl. 2020, 163, 105073. [CrossRef]

4. Del Borghi, A.; Moreschi, L.; Gallo, M. Circular economy approach to reduce water-energy-food nexus. Curr. Opin. Environ. Sci. Health 2020, 13, 23-28. [CrossRef]

5. Jia, F.; Yin, S.; Chen, L.; Chen, X. The circular economy in the textile and apparel industry: A systematic literature review. J. Clean. Prod. 2020, 259, 120728. [CrossRef]

6. Okorie, O.; Salonitis, K.; Charnley, F.; Moreno, M.; Turner, C.; Tiwari, A. Digitisation and the Circular Economy: A Review of Current Research and Future Trends. Energies 2018, 11, 3009. [CrossRef]

7. Sherwood, J. The significance of biomass in a circular economy. Bioresour. Technol. 2020, 300, 122755. [CrossRef] 
8. Rolewicz-Kalińska, A.; Lelicińska-Serafin, K.; Manczarski, P. The Circular Economy and Organic Fraction of Municipal Solid Waste Recycling Strategies. Energies 2020, 13, 4366. [CrossRef]

9. Mhatre, P.; Panchal, R.; Singh, A.; Bibyan, S. A systematic literature review on the circular economy initiatives in the European Union. Sustain. Prod. Consum. 2021, 26, 187-202. [CrossRef]

10. Esposito, B.; Sessa, M.R.; Sica, D.; Malandrino, O. Towards circular economy in the agri-food sector. A systematic literature review. Sustainability 2020, 12, 7401. [CrossRef]

11. Lewandowski, M. Designing the Business Models for Circular Economy-Towards the Conceptual Framework. Sustainability 2016, 8, 43. [CrossRef]

12. Abila, B.; Kantola, J. Waste management: Relevance to environmental sustainability. Int. J. Environ. Waste Manag. 2019, $23,337$. [CrossRef]

13. Bentsen, N.S.; Felby, C.; Thorsen, B.J. Agricultural residue production and potentials for energy and materials services. Prog. Energy Combust. Sci. 2014, 40, 59-73. [CrossRef]

14. FAOSTAT Food and Agriculture Data. Available online: http://www.fao.org/faostat/en/\#home (accessed on 21 November 2020).

15. IPCC. IPCC Fifth Assessment Report (AR5); IPCC: Geneva, Switzerland, 2013.

16. Börjesson, P.I.I. Energy analysis of biomass production and transportation. Biomass Bioenergy 1996, 11, 305-318. [CrossRef]

17. Moliner, C.; Bosio, B.; Arato, E.; Ribes-Greus, A. Comparative study for the energy valorisation of rice straw. Chem. Eng. Trans. 2014, 37, 241-246. [CrossRef]

18. Massaro Sousa, L.; Ferreira, M.C. Spent coffee grounds as a renewable source of energy: An analysis of bulk powder flowability. Particuology 2019, 43, 92-100. [CrossRef]

19. Caicedo, M.; Barros, J.; Ordás, B.; Caicedo, M.; Barros, J.; Ordás, B. Redefining Agricultural Residues as Bioenergy Feedstocks. Materials 2016, 9, 635. [CrossRef]

20. Algieri, A.; Andiloro, S.; Tamburino, V.; Zema, D.A. The potential of agricultural residues for energy production in Calabria (Southern Italy). Renew. Sustain. Energy Rev. 2019, 104, 1-14. [CrossRef]

21. Haghighi Mood, S.; Hossein Golfeshan, A.; Tabatabaei, M.; Salehi Jouzani, G.; Najafi, G.H.; Gholami, M.; Ardjmand, M Lignocellulosic biomass to bioethanol, a comprehensive review with a focus on pretreatment. Renew. Sustain. Energy Rev. 2013, 27, 77-93. [CrossRef]

22. Kan, T.; Strezov, V.; Evans, T.J. Lignocellulosic biomass pyrolysis: A review of product properties and effects of pyrolysis parameters. Renew. Sustain. Energy Rev. 2016, 57, 1126-1140. [CrossRef]

23. Casazza, A.A.; Spennati, E.; Converti, A.; Busca, G. Production of carbon-based biofuels by pyrolysis of exhausted Arthrospira platensis biomass after protein or lipid recovery. Fuel Process. Technol. 2020, 201, 106336. [CrossRef]

24. Bernocco, D.; Bosio, B.; Arato, E. Feasibility study of a spouted bed gasification plant. Chem. Eng. Res. Des. 2013, 91, 843-855. [CrossRef]

25. Greppi, P.; Bosio, B.; Arato, E. Feasibility of the integration of a molten carbonate fuel-cell system and an integrated gasification combined cycle. Int. J. Hydrog. Energy 2009, 34, 8664-8669. [CrossRef]

26. Bentsen, N.S.; Jørgensen, J.R.; Stupak, I.; Jørgensen, U.; Taghizadeh-Toosi, A. Dynamic sustainability assessment of heat and electricity production based on agricultural crop residues in Denmark. J. Clean. Prod. 2019, 213, 491-507. [CrossRef]

27. Albina, D.O. Emissions from multiple-spouted and spout-fluid fluidized beds using rice husks as fuel. Renew. Energy 2006, 31, 2152-2163. [CrossRef]

28. Molino, A.; Chianese, S.; Musmarra, D. Biomass gasification technology: The state of the art overview. J. Energy Chem. 2016, 25, 10-25. [CrossRef]

29. Sharma, A.; Pareek, V.; Zhang, D. Biomass pyrolysis-A review of modelling, process parameters and catalytic studies. Renew. Sustain. Energy Rev. 2015, 50, 1081-1096. [CrossRef]

30. Kim, S.; Dale, B.E. Global potential bioethanol production from wasted crops and crop residues. Biomass Bioenergy 2004, 26, 361-375. [CrossRef]

31. Qambrani, N.A.; Rahman, M.M.; Won, S.; Shim, S.; Ra, C. Biochar properties and eco-friendly applications for climate change mitigation, waste management, and wastewater treatment: A review. Renew. Sustain. Energy Rev. 2017, 79, 255-273. [CrossRef]

32. Gowane, G.R.; Gadekar, Y.P.; Prakash, V.; Kadam, V.; Chopra, A.; Prince, L.L.L. Climate change impact on sheep production: Growth, milk, wool, and meat. In Sheep Production Adapting to Climate Change; Springer: Singapore, 2017; pp. 31-69. ISBN 9789811047145.

33. Sabia, E.; Gauly, M.; Napolitano, F.; Serrapica, F.; Cifuni, G.F.; Claps, S. Dairy sheep carbon footprint and ReCiPe end-point study. Small Rumin. Res. 2020, 185, 106085. [CrossRef]

34. Biswas, W.K.; Graham, J.; Kelly, K.; John, M.B. Global warming contributions from wheat, sheep meat and wool production in Victoria, Australia-a life cycle assessment. J. Clean. Prod. 2010, 18, 1386-1392. [CrossRef]

35. Vagnoni, E.; Franca, A.; Breedveld, L.; Porqueddu, C.; Ferrara, R.; Duce, P. Environmental performances of Sardinian dairy sheep production systems at different input levels. Sci. Total Environ. 2015, 502, 354-361. [CrossRef]

36. Vagnoni, E.; Carrino, C.; Dibenedetto, N.; Pieragostini, E.; Consenti, B. The enhancement of native sheep's wool: Three case studies from some Italian regions. Small Rumin. Res. 2016, 135, 85-89. [CrossRef] 
37. Rajabinejad, H.; Buciscanu, I.-I.; Maier, S.S. Current approaches for raw wool waste management and unconventional valorization: A review. Environ. Eng. Manag. J. 2019, 18, 1439-1456. [CrossRef]

38. Zoccola, M.; Montarsolo, A.; Mossotti, R.; Patrucco, A.; Tonin, C. Green Hydrolysis as an Emerging Technology to Turn Wool Waste into Organic Nitrogen Fertilizer. Waste Biomass Valorization 2015, 6, 891-897. [CrossRef]

39. Bhavsar, P.; Zoccola, M.; Patrucco, A.; Montarsolo, A.; Mossotti, R.; Rovero, G.; Giansetti, M.; Tonin, C. Superheated Water Hydrolysis of Waste Wool in a Semi-Industrial Reactor to Obtain Nitrogen Fertilizers. ACS Sustain. Chem. Eng. 2016, 4, 6722-6731. [CrossRef]

40. Mabaya, G.; Unami, K.; Takeuchi, J.; Fujihara, M.; Yoshioka, H. Robust optimal model for sustainable joint production of green tea and paddy rice in Japanese agricultural watersheds. Int. J. Innov. Sustain. Dev. 2017, 11, 69. [CrossRef]

41. Amheka, A.; Higano, Y.; Mizunoya, T.; Yabar, H. An overview of current household waste management in Indonesia: Development of a new integrated strategy. Int. J. Environ. Waste Manag. 2015, 15, 86. [CrossRef]

42. Das, M.; Verma, O.P.; Patri, D.; Sethi, R. Scope of soil organic carbon sequestration through agro-based industrial wastewater use in different soil types dominated in eastern India. Int. J. Environ. Waste Manag. 2017, 20, 155. [CrossRef]

43. Mieldazys, R.; Jotautiene, E.; Jasinskas, A.; Aboltins, A. The physical mechanical properties evaluation of experimental granulated organic compost fertilizer. Eng. Rural Dev. 2017, 16, 575-580.

44. Chakraborty, D.; Venkata Mohan, S. Effect of food to vegetable waste ratio on acidogenesis and methanogenesis during two-stage integration. Bioresour. Technol. 2018, 254, 256-263. [CrossRef]

45. Editors, G.; Walmsley, T.G.; Varbanov, P.S.; Su, R.; Klemeš, J.J.; Bong, C.P.; Yee Lim, L.; Tin Lee, C.; Van Fan, Y.; Jaromír Klemeš, J. The Role of Smart Waste Management in Smart Agriculture. Chem. Eng. Trans. 2018, 70. [CrossRef]

46. Riera-Vila, I.; Anderson, N.O.; Flavin Hodge, C.; Rogers, M. Anaerobically-Digested Brewery Wastewater as a Nutrient Solution for Substrate-Based Food Production. Horticulturae 2019, 5, 43. [CrossRef]

47. Rendel, J.; Mackay, A.; Smale, P.; Manderson, A.; Scobie, D. Optimisation of the Resource of Land-Based Livestock Systems to Advance Sustainable Agriculture: A Farm-Level Analysis. Agriculture 2020, 10, 331. [CrossRef]

48. Chen, S.; Yang, M.; Ba, C.; Yu, S.; Jiang, Y.; Zou, H.; Zhang, Y. Preparation and characterization of slow-release fertilizer encapsulated by biochar-based waterborne copolymers. Sci. Total Environ. 2018, 615, 431-437. [CrossRef] [PubMed]

49. Bröckel, U.; Hahn, C. Product design of solid fertilizers. Chem. Eng. Res. Des. 2004, 82, 1453-1457. [CrossRef]

50. Rovero, G.; Watkinson, A.P. A two-stage spouted bed process for autothermal pyrolysis or retorting. Fuel Process. Technol. 1990, 26, 221-238. [CrossRef]

51. Rovero, G.; Curti, M.; Cavaglià, G. Optimization of Spouted Bed Scale-Up by Square-Based Multiple Unit Design. Adv. Chem. Eng. 2012. [CrossRef]

52. Marchelli, F.; Curti, M.; Tognin, M.; Rovero, G.; Moliner, C.; Arato, E.; Bosio, B. Experimental Study on the Solids Residence Time Distribution in Multiple Square-Based Spouted Beds. Energies 2020, 13, 4694. [CrossRef]

53. LIFE + GREENWOLF Project. Available online: http://www.life-greenwoolf.eu/ (accessed on 21 November 2020).

54. Progetto Biochar-Trasformazione di Scarti Agricoli Dell'industria Tessile in Char. Available online: https: / / www.pointex.eu/ documents/BIOCHAR.pdf (accessed on 3 January 2021).

55. Moliner, C.; Marchelli, F.; Arato, E. Current Status of Energy Production from Solid Biomass in North-West Italy. Energies 2020, 13, 4390. [CrossRef]

56. Chung, J.N. Grand Challenges in Bioenergy and Biofuel Research: Engineering and Technology Development, Environmental Impact, and Sustainability. Front. Energy Res. 2013, 1, 4. [CrossRef]

57. Spennati, E.; Casazza, A.A.; Converti, A.; Busca, G. Thermocatalytic Pyrolysis of Exhausted Arthrospira platensis Biomass after Protein or Lipid Recovery. Energies 2020, 13, 5246. [CrossRef]

58. Chen, X.; Che, Q.; Li, S.; Liu, Z.; Yang, H.; Chen, Y.; Wang, X.; Shao, J.; Chen, H. Recent developments in lignocellulosic biomass catalytic fast pyrolysis: Strategies for the optimization of bio-oil quality and yield. Fuel Process. Technol. 2019, 196, 106180. [CrossRef]

59. Kabir, G.; Hameed, B.H. Recent progress on catalytic pyrolysis of lignocellulosic biomass to high-grade bio-oil and bio-chemicals. Renew. Sustain. Energy Rev. 2017, 70, 945-967. [CrossRef]

60. Antal, M.J.; Grønli, M. The Art, Science, and Technology of Charcoal Production. Ind. Eng. Chem. Res. 2003, 42, 1619-1640. [CrossRef]

61. Karaosmanoǧlu, F.; Işı̄gīgür-Ergüdenler, A.; Sever, A. Biochar from the Straw-Stalk of Rapeseed Plant. Energy Fuels 2000, 14, 336-339. [CrossRef]

62. Keiluweit, M.; Nico, P.S.; Johnson, M.G.; Kleber, M. Dynamic Molecular Structure of Plant Biomass-Derived Black Carbon (Biochar). Environ. Sci. Technol. 2010, 44, 1247-1253. [CrossRef] [PubMed]

63. Ahmad, M.; Lee, S.S.; Dou, X.; Mohan, D.; Sung, J.-K.; Yang, J.E.; Ok, Y.S. Effects of pyrolysis temperature on soybean stover- and peanut shell-derived biochar properties and TCE adsorption in water. Bioresour. Technol. 2012, 118, 536-544. [CrossRef] [PubMed]

64. Ahmad, M.; Rajapaksha, A.U.; Lim, J.E.; Zhang, M.; Bolan, N.; Mohan, D.; Vithanage, M.; Lee, S.S.; Ok, Y.S. Biochar as a sorbent for contaminant management in soil and water: A review. Chemosphere 2014, 99, 19-33. [CrossRef] [PubMed]

65. Wang, S.; Gao, B.; Zimmerman, A.R.; Li, Y.; Ma, L.; Harris, W.G.; Migliaccio, K.W. Physicochemical and sorptive properties of biochars derived from woody and herbaceous biomass. Chemosphere 2015, 134, 257-262. [CrossRef] [PubMed]

66. Valagussa, M.; Pozzi, A. Il Biochar: Black Revolution; Fondazione Minoprio: Vertemateconmino Pulio, Italy, 2011. 
67. Ding, Y.; Liu, Y.; Liu, S.; Li, Z.; Tan, X.; Huang, X.; Zeng, G.; Zhou, L.; Zheng, B. Biochar to improve soil fertility. A review. Agron. Sustain. Dev. 2016, 36, 36. [CrossRef]

68. Mohan, D.; Sarswat, A.; Ok, Y.S.; Pittman, C.U. Organic and inorganic contaminants removal from water with biochar, a renewable, low cost and sustainable adsorbent-A critical review. Bioresour. Technol. 2014, 160, 191-202. [CrossRef] [PubMed]

69. Hervy, M.; Pham Minh, D.; Gérente, C.; Weiss-Hortala, E.; Nzihou, A.; Villot, A.; Le Coq, L. $\mathrm{H}_{2} \mathrm{~S}$ removal from syngas using wastes pyrolysis chars. Chem. Eng. J. 2018, 334, 2179-2189. [CrossRef]

70. Lee, J.; Kim, K.-H.; Kwon, E.E. Biochar as a Catalyst. Renew. Sustain. Energy Rev. 2017, 77, 70-79. [CrossRef]

71. Gwenzi, W.; Chaukura, N.; Noubactep, C.; Mukome, F.N.D. Biochar-based water treatment systems as a potential low-cost and sustainable technology for clean water provision. J. Environ. Manag. 2017, 197, 732-749. [CrossRef]

72. Cha, J.S.; Park, S.H.; Jung, S.-C.; Ryu, C.; Jeon, J.-K.; Shin, M.-C.; Park, Y.-K. Production and utilization of biochar: A review. J. Ind. Eng. Chem. 2016, 40,1-15. [CrossRef]

73. Woolf, D.; Amonette, J.E.; Street-Perrott, F.A.; Lehmann, J.; Joseph, S. Sustainable biochar to mitigate global climate change. Nat. Commun. 2010, 1, 1-9. [CrossRef]

74. Kuppusamy, S.; Thavamani, P.; Megharaj, M.; Venkateswarlu, K.; Naidu, R. Agronomic and remedial benefits and risks of applying biochar to soil: Current knowledge and future research directions. Environ. Int. 2016, 87, 1-12. [CrossRef] [PubMed]

75. Nanda, S.; Dalai, A.K.; Berruti, F.; Kozinski, J.A. Biochar as an Exceptional Bioresource for Energy, Agronomy, Carbon Sequestration, Activated Carbon and Specialty Materials. Waste Biomass Valoriz. 2016, 7, 201-235. [CrossRef]

76. Garcia-Nunez, J.A.; Pelaez-Samaniego, M.R.; Garcia-Perez, M.E.; Fonts, I.; Abrego, J.; Westerhof, R.J.M.; Garcia-Perez, M. Historical Developments of Pyrolysis Reactors: A Review. Energy Fuels 2017, 31, 5751-5775. [CrossRef]

77. Epstein, N.; Grace, J.R. Spouted and Spout-Fluid Beds; Epstein, N., Grace, J.R., Eds.; Cambridge University Press: Cambridge, UK, 2010; ISBN 9780511777936.

78. Moliner, C.; Marchelli, F.; Bosio, B.; Arato, E. Modelling of spouted and spout-fluid beds: Key for their successful scale up. Energies 2017, 10, 1729. [CrossRef]

79. Alghurabie, I.K.; Hasan, B.O.; Jackson, B.; Kosminski, A.; Ashman, P.J. Fluidized bed gasification of Kingston coal and marine microalgae in a spouted bed reactor. Chem. Eng. Res. Des. 2013, 91, 1614-1624. [CrossRef]

80. Bove, D.; Moliner, C.; Curti, M.; Baratieri, M.; Bosio, B.; Rovero, G.; Arato, E. Preliminary Tests for the Thermo-Chemical Conversion of Biomass in a Spouted Bed Pilot Plant. Can. J. Chem. Eng. 2018. [CrossRef]

81. Lopez, G.; Alvarez, J.; Amutio, M.; Arregi, A.; Bilbao, J.; Olazar, M. Assessment of steam gasification kinetics of the char from lignocellulosic biomass in a conical spouted bed reactor. Energy 2016, 107, 493-501. [CrossRef]

82. Fernandez-Akarregi, A.R.; Makibar, J.; Lopez, G.; Amutio, M.; Olazar, M. Design and operation of a conical spouted bed reactor pilot plant $(25 \mathrm{~kg} / \mathrm{h})$ for biomass fast pyrolysis. Fuel Process. Technol. 2013, 112, 48-56. [CrossRef]

83. Du, S.; Sun, Y.; Gamliel, D.P.; Valla, J.A.; Bollas, G.M. Catalytic pyrolysis of miscanthus giganteus in a spouted bed reactor. Bioresour. Technol. 2014, 169, 188-197. [CrossRef]

84. Niksiar, A.; Nasernejad, B. Activated carbon preparation from pistachio shell pyrolysis and gasification in a spouted bed reactor. Biomass Bioenergy 2017, 106, 43-50. [CrossRef]

85. Beltramo, C.; Rovero, G.; Cavaglià, G. Hydrodynamic and thermal experimentation on square-based spouted beds for polymer upgrading and unit scale-up. Can. J. Chem. Eng. 2009, 87, 394-402. [CrossRef]

86. Marchelli, F.; Moliner, C.; Curti, M.; Bosio, B.; Arato, E. CFD-DEM simulations of a continuous square-based spouted bed and evaluation of the solids residence time distribution. Powder Technol. 2020, 366, 840-858. [CrossRef]

87. Moliner, C.; Marchelli, F.; Spanachi, N.; Martinez-Felipe, A.; Bosio, B.; Arato, E. CFD simulation of a spouted bed: Comparison between the Discrete Element Method (DEM) and the Two Fluid Model (TFM). Chem. Eng. J. 2019, 377, 120466. [CrossRef]

88. Moliner, C.; Marchelli, F.; Ong, L.; Martinez-Felipe, A.; Van der A, D.; Arato, E. Sensitivity analysis and validation of a Two Fluid Method (TFM) model for a spouted bed. Chem. Eng. Sci. 2019, 207, 39-53. [CrossRef]

89. Marchelli, F.; Moliner, C.; Bosio, B.; Arato, E. A CFD-DEM sensitivity analysis: The case of a pseudo-2D spouted bed. Powder Technol. 2019, 353, 409-425. [CrossRef]

90. Eurostat Sheep Population Data. Available online: https:/ / ec.europa.eu/eurostat (accessed on 21 November 2020).

91. Tonin, C. Trasformazione Delle Lane di Scarto in Fertilizzanti Organici Mediante Idrolisi Con Acqua Surriscaldata. Available online: https:/ / www.reterurale.it/flex/cm/pages/ServeBLOB.php/L/IT/IDPagina/18912/UT/systemPrint (accessed on 21 November 2020).

92. Commission Regulation (EU) No. 142/2011 of 25 February 2011 Implementing Regulation (EC) No. 1069/2009 of the European Parliament and of the Council Laying down Health Rules as Regards Animal by-Products and Derived Products not Intended for Human Consumption and Repealing Regulation (EC) No. 1774/2002. Available online: http://data.europa.eu/eli/reg/2009/106 9/ oj (accessed on 21 November 2020).

93. Yasin, S.; Curti, M.; Rovero, G.; Hussain, M.; Sun, D. Spouted-Bed Gasification of Flame Retardant Textiles as a Potential Non-Conventional Biomass. Appl. Sci. 2020, 10, 946. [CrossRef]

94. Alyousef, R.; Alabduljabbar, H.; Mohammadhosseini, H.; Mohamed, A.M.; Siddika, A.; Alrshoudi, F.; Alaskar, A. Utilization of sheep wool as potential fibrous materials in the production of concrete composites. J. Build. Eng. 2020, 30, 101216. [CrossRef]

95. Bosia, D.; Savio, L.; Thiebat, F.; Patrucco, A.; Fantucci, S.; Piccablotto, G.; Marino, D. Sheep wool for sustainable architecture. In Proceedings of the Energy Procedia; Elsevier Ltd.: Amsterdam, The Netherlands; Turin, Italy, 2015; Volume 78, pp. 315-320. 
96. Borlea (Mureşan), S.I.; Tiuc, A.-E.; Nemeş, O.; Vermeşan, H.; Vasile, O. Innovative Use of Sheep Wool for Obtaining Materials with Improved Sound-Absorbing Properties. Materials 2020, 13, 694. [CrossRef] [PubMed]

97. Enkhzaya, S.; Shiomori, K.; Oyuntsetseg, B. Effective adsorption of Au(III) and Cu(II) by chemically treated sheep wool and the binding mechanism. J. Environ. Chem. Eng. 2020, 8, 104021. [CrossRef]

98. Lal, B.; Sharma, S.C.; Meena, R.L.; Sarkar, S.; Sahoo, A.; Balai, R.C.; Gautam, P.; Meena, B.P. Utilization of byproducts of sheep farming as organic fertilizer for improving soil health and productivity of barley forage. J. Environ. Manag. 2020, $269,110765$. [CrossRef] [PubMed]

99. Hustvedt, G.; Meier, E.; Waliczek, T. The feasibility of large-scale composting of waste wool. In Environmental Footprints and Eco-Design of Products and Processes; Springer: Berlin/Heidelberg, Germany, 2016; pp. 95-107.

100. Maclaren, J.A. Wool Science: The Chemical Reactivity of the Wool Fibre; Science Press: Marrickville, Australia, 1981 ; ISBN 0855830913.

101. Vasconcelos, A.; Cavaco-Paulo, A. The Use of Keratin in Biomedical Applications. Curr. Drug Targets 2013, 14, 612-619. [CrossRef]

102. Zoccola, M.; Aluigi, A.; Patrucco, A.; Tonin, C. Extraction, processing and applications of wool keratin. In Keratin Structure, Properties and Applications; Dullaart, R., Mousquès, J., Eds.; Nova Science Publishers: New York, NY, USA, 2012.

103. Von Bergen, W. Wool Handbook, 3rd ed.; John Wiley \& Sons: Hoboken, NJ, USA, 1970; ISBN 0471910163.

104. Gousterova, A.; Nustorova, M.; Goshev, I.; Christov, P.; Braikova, D.; Tishinov, K.; Haertlé, T.; Nedkov, P. Alkaline hydrolysate of waste sheep wool aimed as fertilizer. Biotechnol. Biotechnol. Equip. 2003, 17, 140-145. [CrossRef]

105. Nustorova, M.; Braikova, D.; Gousterova, A.; Vasileva-Tonkova, E.; Nedkov, P. Chemical, microbiological and plant analysis of soil fertilized with alkaline hydrolysate of sheep's wool waste. World J. Microbiol. Biotechnol. 2006, 22, 383-390. [CrossRef]

106. Petek, B.; Marinšek Logar, R. Management of waste sheep wool as valuable organic substrate in European Union countries. J. Mater. Cycles Waste Manag. 2020, 1-11. [CrossRef]

107. Berechet, M.D.; Niculescu, M.D.; Gaidau, C.; Ignat, M.; Epure, D.G. Alkaline-enzymatic hydrolysis of wool waste for different applications. Rev. Chim. 2018, 69, 1649-1654. [CrossRef]

108. Eslahi, N.; Dadashian, F.; Nejad, N.H. An investigation on keratin extraction from wool and feather waste by enzymatic hydrolysis. Prep. Biochem. Biotechnol. 2013, 43, 624-648. [CrossRef] [PubMed]

109. Zoccola, M.; Aluigi, A.; Patrucco, A.; Vineis, C.; Forlini, F.; Locatelli, P.; Sacchi, M.C.; Tonin, C. Microwave-assisted chemical-free hydrolysis of wool keratin. Text. Res. J. 2012, 82, 2006-2018. [CrossRef] 